\title{
Genotoxicity of fixation devices analyzed by the frequencies of sister chromatid exchange
}

\author{
Fiksasyon araçlarının genotoksisitesinin kardeş \\ kromatit değişim sıklığgiyla analizi
}

\author{
Barış Altuğ AYDİL, ${ }^{1}$ Hülya KOÇAK BERBEROĞLU, ${ }^{1}$ Sükrü ÖZTÜRK, ${ }^{2}$ \\ Kıvanç CEFLE, ${ }^{2}$ Şükrü PALANDÜZ, ${ }^{2}$ Haluk ERKAL ${ }^{2}$
}

\section{BACKGROUND}

Metal alloys utilized in the management of jaw fractures may exert genotoxic effects. Our purpose was to compare the genotoxicity of intermaxillary fixation devices containing nickel and chromium to that of titanium miniplates utilized in treatment of jaw fractures through the analysis of sister chromatid exchange.

\section{METHODS}

In this prospective study, in a total of 28 non-smoker patients (10 females, 18 males; mean age $33.43 \pm 10.76$; range 15 to 60 years) with jaw fractures, 14 were treated with intermaxillary fixation by administration of nickel-chromium wire and arch bar and 14 with titanium miniplates to investigate the genotoxicity of different metal alloys. The outcome variable was the frequency of sister chromatide exchange in peripheral lymphoctyes, determined through the analysis of venous blood samples obtained preoperatively and 4 to 6 weeks postoperatively.

\section{RESULTS}

The frequency of the average sister chromatid exchange was found to be significantly higher in patients treated with the nickel-chromium intermaxillary fixation devices than those treated by titanium miniplates $(1.29 \pm 0.29$ vs. $0.46 \pm 0.39, \mathrm{p}<0.001)$.

\section{CONCLUSION}

Although titanium miniplate osteosynthesis is an invasive technique in comparison with the nickel-chromium-containing intermaxillary fixation devices, titanium seems to exert less genotoxic effect than the nickel-chromium alloy. However, this finding should be supported in clinical studies with a larger sampling size.

Key Words: Genotoxicity; intermaxillary fixation; nickel-chromium alloy; sister chromatid exchange; titanium; titanium miniplate osteosynthesis.

\section{AMAÇ}

Çene kırıklarının tedavisinde kullanılan metal alaşımları genotoksik etkilere yol açabilir. Amacımız, kardeş kromatit değişim sıklığının analiziyle, çene kırıklarının tedavisinde kullanılan nikel-krom içerikli intermaksiller fiksasyon araçları ve titanyum miniplakların genotoksisitelerini karşılaştırmaktır.

\section{GEREÇ VE YÖNTEM}

$\mathrm{Bu}$ ileriye yönelik çalışmada, farklı metal alaşımlarının genotoksisitesini araştırmak için çene kırığı bulunan ve sigara içmeyen toplam 28 hastanın (10 kadın, 18 erkek; ortalama

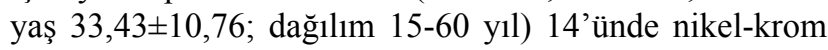
içerikli ark bar ve tel uygulanmasıyla intermaksiller fiksasyon gerçekleştirilirken diğer 14'üne titanyum miniplak tedavisi uygulandı. Sonuç değişkeni ameliyat öncesinde ve ameliyattan dört-altı hafta sonra alınan venöz kan örneklerindeki periferal lenfositlerde görülen kardeş kromatit değişiminin sıklığıydı.

\section{BULGULAR}

Ortalama kardeş kromatit değişim sıklığının nikel-krom içerikli intermaksiller fiksasyon araçlarıyla tedavi edilen hastalarda titanyum miniplaklarla tedavi edilenlere oranla önemli ölçüde daha yüksek olduğu gözlendi $(1,29 \pm 0,29$ ve $0,46 \pm 0,39, \mathrm{p}<0,001)$.

\section{SONUÇ}

Her ne kadar titanyum miniplak osteosentezi nikel-krom içerikli intermaksiller fiksasyon araçlarına kıyasla daha invaziv bir teknik ise de, titanyumun nikel-krom alaşımından daha az genotoksik etkiye yol açtığı görülmektedir. Ancak bu bulgu daha geniş örneklem büyüklüğüyle gerçekleştirilen klinik çalışmalarla desteklenmelidir.

Anahtar Sözcükler: Genotoksisite; intermaksiller fiksasyon; nikel-krom alaşımı; kardeş kromatit değişimi; titanyum; titanyum miniplak osteosentezi.

\footnotetext{
${ }^{1}$ Department of Oral and Maxillofacial Surgery,

Istanbul University Faculty of Dentistry, Istanbul;

${ }^{2}$ Department of Internal Medicine, Division of Genetics,

Istanbul University Faculty of Medicine, Istanbul, Turkey.
}

${ }^{1}$ İstanbul Üniversitesi Diş Hekimliği Fakültesi,

Ağız Diș ve Cene Cerrahisi Anabilim Dalı, İstanbul;

${ }^{2}$ İstanbul Üniversitesi Tıp Fakültesi, Dahiliye Anabilim Dalı, T1bbi Genetik Bölümü, İstanbul. 
Fracture is the partial or total loss of bone integrity due to a trauma or a pathologic condition. ${ }^{[1,2]}$ In the treatment of fractures, the main goal is to restore the functional integrity by bringing the fractured portions of the jaw into normal anatomical position, which is also termed as fracture reduction. ${ }^{[3,4]}$ This is followed by fixation through which the fractured parts are held in their anatomical positions until the healing is complete. ${ }^{[5-7]}$ The materials used for intermaxillary fixation (IMF) encompass arch bars, ligature wires, pins, screws, and plates, which are made of various metals. The fixative elements such as plates, pins, wires, and screws submerged in the bone are composed of different metals that may lead to local or systemic reactions over time. ${ }^{[7-10]}$ While several studies ${ }^{[8,11,12]}$ have reported on the local tissue reactions led by metals left in situ after healing, there are only a few reports on the systemic effects of metallic elements used for fracture treatment. ${ }^{[12-16]}$

The analysis of sister chromatid exchange (SCE) is a sophisticated cytomolecular technique used in research studies for determination of genotoxicity. ${ }^{[17-20]}$ The analysis of SCE indicates clastogenic, genotoxic and genetic instabilities in chromosomes as demonstrated by discrete stainings in the symmetrical segments of the chromatids. ${ }^{[19-22]}$

In various lesions, SCE may increase under the influence of ultraviolet light and X-ray radiation, chemicals or even spontaneously. In determination of the mutagenic effects or genotoxic potential of chemicals, SCE is more sensitive than chromatid breaks, gaps and the figures of exchange. Mutagens and carcinogens can cause significant increase in the frequency of SCE, even in concentrations that would not cause chromosome breaks. SCE is thought to take place in the replication point, and SCE analysis is a technique used to study the effect of many chemical mutagens. ${ }^{[19,20,22-24]}$

In this study, our main purpose was to investigate the genotoxicity of different metal alloys used for the fixation of jaw fractures through the analysis of SCE.

\section{MATERIALS AND METHODS}

This prospective study was carried out in a total of 28 patients with jaw fractures (10 females, 18 males; all non-smokers; mean age $33.43 \pm 10.76$; range 15 to 60 years) who referred to the Department of Oral and Maxillofacial Surgery, Faculty of Dentistry, Istanbul University, Istanbul, Turkey, between January 2002 and June 2008. The patients with a systemic infection, malignant disorder, history of cytotoxic or narcotic drug administration, smokers, and workers who could have been subjected to metal dusts were not included in the study. All patients signed an informed consent, prepared in accordance with the Declaration of Hel- sinki, which was reviewed and approved by the local ethics committee of our institution.

In the treatment of 14 patients through IMF procedure, a durable, stainless and flexible arch bar containing aluminum (58-65\%), chromium (17-30\%), iron (15-20\%), and nickel (13-16\%) and a ligature wire composed of vitallium (30-40\%), chromium (17-25\%), iron (15-20\%), nickel (13-16\%), and molybdenum (2.25-3.5\%) were used. The metal elements utilized for IMF were left in place for 4-6 weeks. In the treatment of 14 patients with titanium miniplate osteosynthesis (TMO), a durable, stainless and biocompatible grade I-IV amorphous titanium alloy miniplate containing titanium $(99.5 \%)$, iron $(0.2 \%)$, oxygen $(0.1 \%)$, carbon $(0.08 \%)$, nitrogen $(0.05 \%)$, and hydrogen $(0.013 \%)$ was utilized. Generally, the miniplates with 4 or 6 holes (20x2x0.9 mm in dimension) were preferred and stabilized using titanium screws in lengths of $5,7,9,11$ or $13 \mathrm{~mm}$.

In the venous blood samples obtained before and 4-6 weeks after the IMF and TMO surgery, the frequencies of SCE in the peripheral blood lymphocytes were investigated. The peripheral blood lymphocytes were cultured for 72 hours in dark medium containing $0.5 \mu \mathrm{g} / \mathrm{ml}$ bromodeoxyuridine (BrdU), which was added 24 hours after the initial culturing process. The metaphase plates were obtained after the standard harvest procedure and stained by Fluorescent-plusGiemsa (FPG) technique. Using a light microscope (Leitz-Ortoplan), the counts of SCE and their distributions in chromosomes were evaluated after selecting clear-cut metaphases under x100 magnification. A terminal change was counted as a single change and the interstitial changes as dual changes. Through the assessment of 30 metaphases in each case, the average SCE per metaphase before and after treatment was calculated by dividing the total count of SCE by the number of metaphases analyzed (Fig. 1).

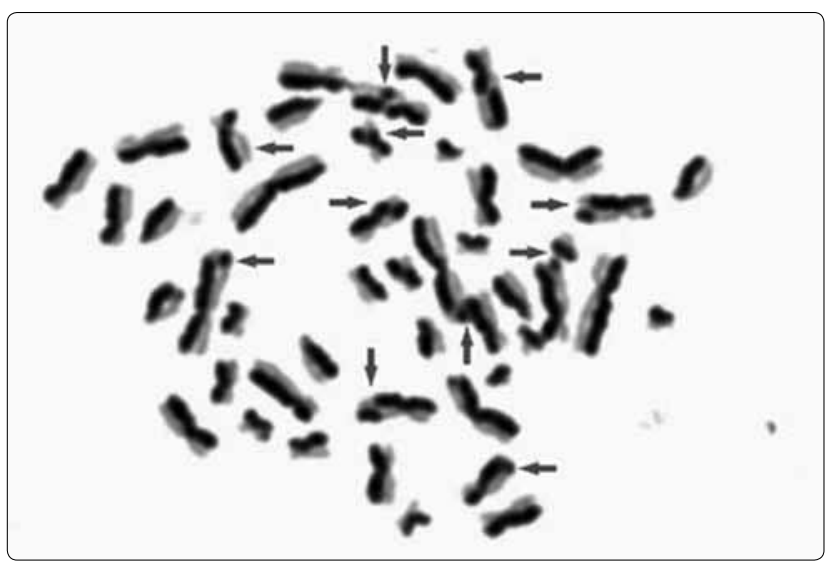

Fig. 1. Arrows indicating the sister chromatid exchange in chromosomal sites. 


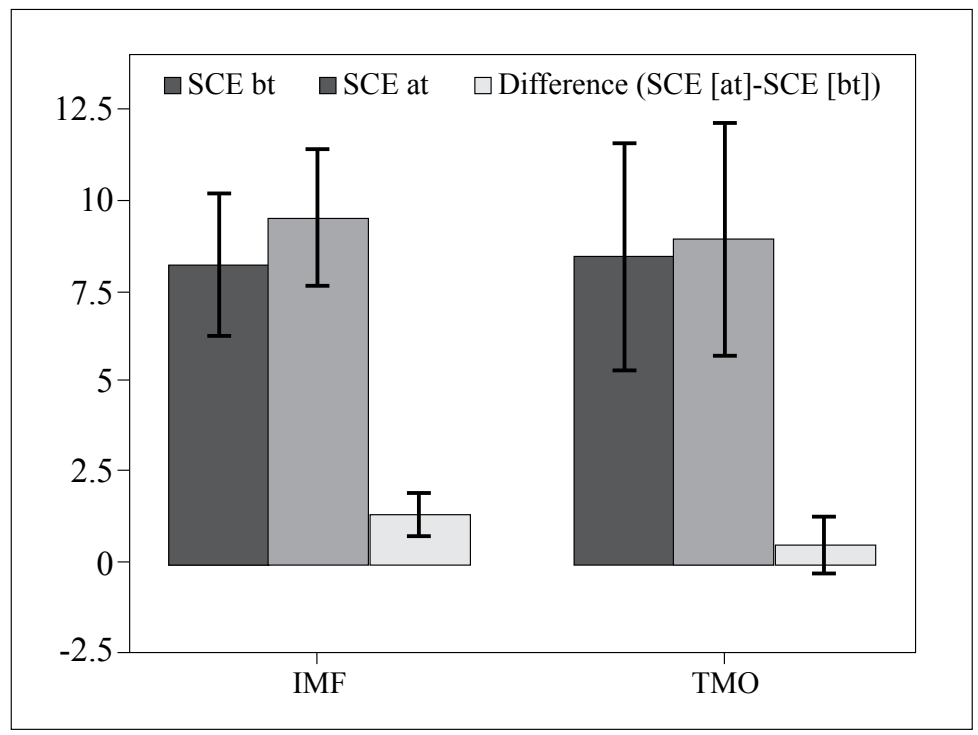

Fig. 2. Diagram showing the average frequencies of SCE in patients treated with nickel chromium-containing intermaxillary fixation (IMF) devices or titanium miniplate osteosynthesis (TMO). The average frequency of SCE in the IMF patients is significantly higher than in TMO patients ( $\mathrm{p}=0.001$, Mann-Whitney U-test).

The Mann-Whitney U-test and the Wilcoxon signed ranks tests were performed for the statistical analyses of the data obtained from independent and dependent variables, respectively. The Statistical Package for the Social Sciences (SPSS) software (version 15; SPSS, Inc., Chicago, IL) was used for statistical analyses, and a $p$ value less than 0.05 was considered statistically significant.

\section{RESULTS}

Of the 28 fractures treated, 25 were mandibular fractures and 3 were maxillary fractures. In 14 patients, 12 unilateral fractures and 2 bilateral fractures were treated by IMF procedure. In 14 patients, TMO procedure was carried out for the treatment of 5 unilateral, 5 bilateral and 4 complex fractures (Table 1). Before the treatment, there was no statistically signifi-

Table 1. The types of fractures and treatments

\begin{tabular}{lcc}
\hline Type of fracture & & \\
\hline Mandibular fracture & 25 & \\
Maxillary fracture & 3 & \\
Total & 28 & \\
\hline Type of treatment & TMO & IMF \\
\hline Unilateral fracture & 5 & 12 \\
Bilateral fracture & 5 & 2 \\
Complex fracture & 4 & \\
Total & 14 & 14 \\
\hline
\end{tabular}

TMO: Titanium miniplate osteosynthesis; IMF: Intermaxillary fixation. cant difference between the average frequency of SCE in the peripheral lymphocytes of the patients treated by IMF or TMO $(8.25 \pm 0.96 v s .8 .45 \pm 1.57, \mathrm{p}=0.963)$. After the treatment, the average frequency of SCE significantly changed in both groups, reaching $9.54 \pm 0.93$ $(\mathrm{p}=0.001)$ and $8.92 \pm 1.6(\mathrm{p}=0.001)$ in IMF patients and TMO patients, respectively (Tables 2,3 ). The average frequency of SCE in the peripheral lymphocytes was significantly higher in the patients treated by IMF than in those treated by TMO $(1.29 \pm 0.29$ vs. $0.46 \pm 0.39$, $\mathrm{p}<0.001$ ) (Fig. 2).

\section{DISCUSSION}

There is still controversy as to whether the fixation devices should be removed or left in situ due to their possible local tissue reactions in addition to any systemic effects. Therefore, the genotoxic potential of different metal alloys used for fracture fixation has been investigated in research studies.

In this study, the patients treated with IMF were probably exposed to nickel and chromium ions released from the arch bar and ligature wire. The increase in the frequency of SCE in peripheral lymphocytes of these patients was statistically significant $(1.29 \pm 0.29$ vs. $0.46 \pm 0.39, \mathrm{p}<0.001)$. This was consistent with the findings of other studies carried out in patients exposed to nickel and chromium ions through the systemic route or inhalation. ${ }^{[22-25]}$ Torgersen et al. ${ }^{[26]}$ reported an increase in transformation of lymphocytes and allergic reactions due to nickel alloy in patients treated by IMF. Merritt and Brown ${ }^{[27]}$ indicated that particularly the ions of chromium, cobalt and nickel released from 
Table 2. Demographic data and the frequency of SCE observed before and after treatment in IMF patients

\begin{tabular}{cccccccc}
\hline No. & Patients & Age & Gender & Type of treatment & SCEbt & SCEat & $\begin{array}{c}\text { Difference } \\
\text { (SCEat)-(SCEbt) }\end{array}$ \\
\hline 1 & AC & 31 & Male & Intermaxillary fixation & 7.2 & 9.2 & 2.0 \\
2 & BB & 37 & Male & Intermaxillary fixation & 8.6 & 9.8 & 1.2 \\
3 & CD & 22 & Male & Intermaxillary fixation & 7.2 & 8.4 & 1.2 \\
4 & HS & 35 & Male & Intermaxillary fixation & 8.7 & 9.8 & 1.1 \\
5 & IV & 42 & Male & Intermaxillary fixation & 7.8 & 8.7 & 0.9 \\
6 & MC & 23 & Female & Intermaxillary fixation & 8.9 & 10.2 & 1.3 \\
7 & MB & 18 & Male & Intermaxillary fixation & 10.2 & 11.3 & 1.1 \\
8 & NK & 36 & Female & Intermaxillary fixation & 6.8 & 7.9 & 1.1 \\
9 & NU & 60 & Male & Intermaxillary fixation & 9.2 & 10.4 & 1.2 \\
10 & ST & 32 & Female & Intermaxillary fixation & 7.9 & 9.4 & 1.5 \\
11 & SE & 36 & Female & Intermaxillary fixation & 7.6 & 9.4 & 1.8 \\
12 & TA & 35 & Male & Intermaxillary fixation & 9.2 & 10.6 & 1.4 \\
13 & MU & 36 & Male & Intermaxillary fixation & 8.7 & 9.9 & 1.2 \\
14 & RC & 21 & Male & Intermaxillary fixation & 7.5 & 8.6 & 1.1 \\
& & & & & $8.25 \pm 0.96$ & $9.54 \pm 0.93$ & $1.29 \pm 0.29$ (Mean \pm StD) \\
\hline
\end{tabular}

SCEbt: Sister chromatid exchange before treatment; SCEat: Sister chromatid exchange after treatment; StD: Standard deviation.

Table 3. Demographic data and the frequency of SCE observed before and after treatment in TMO patients

\begin{tabular}{lccccccc}
\hline No. & Patients & Age & Gender & Type of treatment & SCEbt & SCEat & $\begin{array}{c}\text { Difference } \\
\text { (SCEat)-(SCEbt) }\end{array}$ \\
\hline 15 & AM & 19 & Male & TMO & 9.8 & 10.2 & 0.4 \\
16 & AT & 21 & Male & TMO & 10.7 & 11.0 & 0.3 \\
17 & AC & 43 & Female & TMO & 10.02 & 11.0 & 0.98 \\
18 & BC & 41 & Male & TMO & 7.9 & 8.6 & 0.7 \\
19 & ES & 43 & Male & TMO & 6.8 & 7.6 & 0.8 \\
20 & EC & 35 & Male & TMO & 11.0 & 11.2 & 0.2 \\
21 & FC & 15 & Male & TMO & 10.1 & 11.0 & -0.3 \\
22 & GU & 42 & Female & TMO & 8.7 & 8.4 & 0.4 \\
23 & HB & 39 & Female & TMO & 6.8 & 7.2 & -0.2 \\
24 & KA & 15 & Female & TMO & 7.4 & 7.2 & 0.9 \\
25 & MT & 50 & Male & TMO & 6.9 & 7.8 & 0.7 \\
26 & MO & 29 & Male & TMO & 7.2 & 7.9 & 0.4 \\
27 & SI & 37 & Female & TMO & 8.3 & 6.7 & 0.3 \\
28 & MM & 43 & Female & TMO & 6.8 & $8.92 \pm 1.6$ & $0.46 \pm 0.39$ (Mean \pm StD) \\
\hline
\end{tabular}

SCEbt: Sister chromatid exchange before treatment; SCEat: Sister chromatid exchange after treatment; TMO: Titanium miniplate osteosynthesis; StD: Standard deviation.

a metal alloy through corrosion have toxic effects. The toxic ions of cobalt and nickel are excreted quickly through the urinary tract whereas the ions of chromium are stored in tissues and slowly migrate to the urinary tract. In comparison with the controls consisting of healthy, smoker and non-smoker subjects, Jelmert et al. ${ }^{[24]}$ found a statistically significant increase in the frequency of SCE in the peripheral lymphocytes of the 42 workers directly exposed to nickel and chromium ions in a welding factory manufacturing metal arches containing stainless steel. In an in-vitro study, Katsifis et al. ${ }^{[28]}$ incubated the cell cultures containing $\mathrm{NiSO}_{4}$ and chromium with the heparinized blood samples from non-smokers who were not previously exposed to the dusts of heavy metals and not showing signs of DNA damage. They indicated that nickel (II) and chromium (VI) increased the frequency of SCE in peripheral lymphocytes. In our study, attention was paid to eliminate the smokers, those patients ever exposed to cytotoxic drugs, and workers who could have been subjected to metal dusts, since smoking, cytotoxic drugs and inhaled metal dusts could lead to an increase 
in the frequency of SCE. ${ }^{[29,30]}$ Nevertheless, food additives and preservatives such as sodium benzoate and potassium benzoate commonly used as antimicrobial substances in many kinds of foods (e.g. marinated fish, fruit-based fillings, jam, salad dressing, soft drinks, and beer) have been reported to significantly increase the frequency of SCE in-vitro. ${ }^{[31]}$ Therefore, the possible role of these substances should not be disregarded with respect to the non-significantly and significantly higher frequencies of SCE in the TMO and IMF patients, respectively.

In summary, the increase in the frequency of SCE was significant when arch bars and wires containing nickel and chromium were used for IMF, which is a non-invasive technique. On the other hand, the change in the frequency of SCE was not significant when the invasive TMO technique was performed with the use of plates and screws containing titanium alloy. The long-term follow-up of these patients was not possible due to the high costs of test kits used for determination of the SCE frequency.

In conclusion, 4 to 6 weeks after treatment, the materials containing nickel and chromium alloy used in IMF significantly increased the frequency of SCE in peripheral blood lymphocytes. On the other hand, the plates and screws containing titanium alloy used in TMO did not lead to significant changes in the frequency of SCE after treatment. Even though our results indicate that titanium alloys are less genotoxic than nickel and chromium alloys, this should be confirmed in clinical studies with a larger sampling size.

Conflict-of-interest issues regarding the authorship or article: None declared.

\section{REFERENCES}

1. Haug RH, Greenberg AM. Principles of internal fixation etiology. Distribution and classification of fractures. In: Greenberg AM, editor. Craniomaxillofacial fractures: principles of internal fixation using the AO/ASIF technique. New York: Springer-Verlag; 1993. p. 5-19.

2. King RE, Scianna JM, Petruzzelli GJ. Mandible fracture patterns: a suburban trauma center experience. Am J Otolaryngol 2004;25:301-7.

3. Ellis E 3rd, Graham J. Use of a 2.0-mm locking plate/screw system for mandibular fracture surgery. J Oral Maxillofac Surg 2002;60:642-6.

4. Erol B, Tanrikulu R, Görgün B. Maxillofacial fractures. Analysis of demographic distribution and treatment in 2901 patients (25-year experience). J Craniomaxillofac Surg 2004;32:308-13.

5. Champy M, Loddé JP, Schmitt R, Jaeger JH, Muster D. Mandibular osteosynthesis by miniature screwed plates via a buccal approach. J Maxillofac Surg 1978;6:14-21.

6. Sakr K, Farag IA, Zeitoun IM. Review of 509 mandibular fractures treated at the University Hospital, Alexandria, Egypt. Br J Oral Maxillofac Surg 2006;44:107-11.

7. Marks SC Jr, Popoff SN. Bone cell biology: the regulation of development, structure, and function in the skeleton. Am J
Anat 1988;183:1-44.

8. Taglialatela Scafati C, Facciuto E, Aliberti F. The Elastic Internal Traction (EIT): an effective method to reduce the displaced facial fractures. Int J Oral Maxillofac Surg 2004;33:709-12.

9. Roccia F, Tavolaccini A, Dell'Acqua A, Fasolis M. An audit of mandibular fractures treated by intermaxillary fixation using intraoral cortical bone screws. J Craniomaxillofac Surg 2005;33:251-4.

10. Brown JS, Grew N, Taylor C, Millar BG. Intermaxillary fixation compared to miniplate osteosynthesis in the management of the fractured mandible: an audit. Br J Oral Maxillofac Surg 1991;29:308-11.

11. Fordyce AM, Lalani Z, Songra AK, Hildreth AJ, Carton AT, Hawkesford JE. Intermaxillary fixation is not usually necessary to reduce mandibular fractures. Br J Oral Maxillofac Surg 1999;37:52-7.

12. Thor A, Andersson L. Interdental wiring in jaw fractures: effects on teeth and surrounding tissues after a one-year follow-up. Br J Oral Maxillofac Surg 2001;39:398-401.

13. Jones JK, Van Sickels JE. Rigid fixation: a review of concepts and treatment of fractures. Oral Surg Oral Med Oral Pathol 1988;65:13-8.

14. Laine P, Kontio R, Lindqvist C, Suuronen R. Are there any complications with bioabsorbable fixation devices? A 10 year review in orthognathic surgery. Int J Oral Maxillofac Surg 2004;33:240-4.

15. Langford RJ, Frame JW. Surface analysis of titanium maxillofacial plates and screws retrieved from patients. Int J Oral Maxillofac Surg 2002;31:511-8.

16. Iizuka T, Lindqvist C. Rigid internal fixation of mandibular fractures. An analysis of 270 fractures treated using the $\mathrm{AO} /$ ASIF method. Int J Oral Maxillofac Surg 1992;21:65-9.

17. Celi K A, Akbaş E. Evaluation of sister chromatid exchange and chromosomal aberration frequencies in peripheral blood lymphocytes of gasoline station attendants. Ecotoxicol Environ Saf 2005;60:106-12.

18. Garry VF, Nelson RL, Whorton EP, Wiencke JK. Chromosomal aberrations and sister-chromatid exchanges in tool and die workers. Mutat Res 1989;225:1-9.

19. Gennart JP, Baleux C, Verellen-Dumoulin C, Buchet JP, De Meyer R, Lauwerys R. Increased sister chromatid exchanges and tumor markers in workers exposed to elemental chromium-, cobalt- and nickel-containing dusts. Mutat Res 1993;299:55-61.

20. Wise JP, Orenstein JM, Patierno SR. Inhibition of lead chromate clastogenesis by ascorbate: relationship to particle dissolution and uptake. Carcinogenesis 1993;14:429-34.

21. Sorsa M, Ojajärvi A, Salomaa S. Cytogenetic surveillance of workers exposed to genotoxic chemicals: preliminary experiences from a prospective cancer study in a cytogenetic cohort. Teratog Carcinog Mutagen 1990;10:215-21.

22.Zakharov AF, Egolina NA. Differential spiralization along mammalian mitotic chromosomes. I. BUdR-revealed differentiation in Chinese hamster chromosomes. Chromosoma 1972;38:341-65.

23. Savarino L, Stea S, Granchi D, Visentin M, Ciapetti G, Donati $\mathrm{ME}$, et al. Sister chromatid exchanges and ion release in patients wearing fracture fixation devices. J Biomed Mater Res 2000;50:21-6.

24. Jelmert O, Hansteen IL, Langård S. Chromosome damage in lymphocytes of stainless steel welders related to past and 
current exposure to manual metal arc welding fumes. Mutat Res 1994;320:223-33.

25. Sahu RK, Katsifis SP, Kinney PL, Christie NT. Ni(II) induced changes in cell cycle duration and sister-chromatid exchanges in cultured human lymphocytes. Mutat Res 1995;327:217-25.

26. Torgersen S, Gilhuus-Moe OT, Gjerdet NR. Immune response to nickel and some clinical observations after stainless steel miniplate osteosynthesis. Int J Oral Maxillofac Surg 1993;22:246-50.

27. Merritt K, Brown SA. Distribution of cobalt chromium wear and corrosion products and biologic reactions. Clin Orthop Relat Res 1996:233-43.

28. Katsifis SP, Kinney PL, Hosselet S, Burns FJ, Christie NT. Interaction of nickel with mutagens in the induction of sis- ter chromatid exchanges in human lymphocytes. Mutat Res 1996;359:7-15.

29. Oztürk S, Vatansever S, Cefle K, Palanduz S, Güler K, Erten $\mathrm{N}$, et al. Acute wood or coal exposure with carbon monoxide intoxication induces sister chromatid exchange. J Toxicol Clin Toxicol 2002;40:115-20.

30. Wong RH, Wang JD, Hsieh LL, Du CL, Cheng TJ. Effects on sister chromatid exchange frequency of aldehyde dehydrogenase 2 genotype and smoking in vinyl chloride workers. Mutat Res 1998;420:99-107.

31.Zengin N, Yüzbaşıoglu D, Unal F, Yılmaz S, Aksoy H. The evaluation of the genotoxicity of two food preservatives: sodium benzoate and potassium benzoate. Food Chem Toxicol 2011;49:763-9. 